\title{
Desertification Winter Pasture and Measures against Them
}

\author{
RAE Aliyev ZH* and Babayeva KM \\ Institute of Soil Science and Agrochemistry of NAS of Azerbaijan, Azerbaijan \\ *Corresponding author: RAE Aliyev ZH, Institute of Soil Science and Agrochemistry of NAS of Azerbaijan, Azerbaijan, Email: zakirakademik@mail.ru
}

Submission: 漹 June 01, 2018; Published: 址 June 20, 2018

\begin{abstract}
Erosive processes are detrimental to agriculture, with meadows and pastures lose their fertility potential. However, natural factors, influence of anthropogenic environmental factors exacerbate the situation, creating conditions for the development of desertification. The decline of soil fertility in qualitative and quantitative content of forage land productivity, which in turn leads to a decrease in livestock production. The seeding of legume-grass on winter pastures strengthens eroded the soil, improves water-physical properties, soil nutrient status, increases the productivity of pastures and is a means of combating desertification.
\end{abstract}

Keywords: Winter pastures; Desertification; Erosion of the soil; Degradation; Perennial grasses; Mineralnye fertilizer; Yield

\section{Introduction}

The Republic of Azerbaijan since ancient times, different livestock industry. Our land with rich natural pastures and pastures located in Alpine and subalpine zones is a natural forage resource. However, due to various circumstances, including soil erosion, these natural forage resources lose their fertility potential. One such circumstance is soil erosion. The word "Erosion" in translation from Latin means destruction and is used in the scientific literature in a wide scale. But as a geological term under the soil erosion means the destruction of the upper layer of the Earth's crust under the influence of wind and water. Soil erosion is also human factors, improper conversion to croplands territory, failure of complex erosion agrotechnical measures, overtime grazing cattle. At the present stage of development of agriculture in the period of market economy, the fight against soil erosion is becoming very acute national economic value. Human life is inextricably linked with the land, with the soil, which is the greatest natural wealth. For many millennia, people are not nenosil nature noticeable damage, but the technological revolution disturbed the balance between man and nature. With the development of agriculture human impact on nature became more noticeable. Soil erosion is a natural process in nature, but under anthropogenic influence it becomes widespread. Pastures goes overgrazing and destruction of pavement cover holding the fertile soil layer. Flowing streams eroded the soil, causing extensive erosion. Agricultural development and uplifting of the Republic's economy to improve the well-being of the population depends on the rational use of the soil. But environmental instability, climate change harms Agriculture. Climate change, which, according to scientists, the inherent pollution Wednesday, affect different spheres of life, including agriculture. Scientists found that intensive increase of carbon dioxide on the planet is accompanied by the combustion of different fuels: coal, oil and gas the oxidation of carbon in soils etc Increase medium-world air temperature can change the progress of the natural processes of the biosphere.

The problem of climate change as a result of greenhouse gas emissions should be regarded as one of the most important contemporary issues related to long-term impacts on the environment and the need to consider it Wednesday, coupled with other issues caused by anthropogenic impacts on nature.

In 1988, the General Assemblies of UNPO was established the Intergovernmental Panel on climate change. In tasks of this group was to evaluate the State of the issue and draw attention to it world leaders. A scientist was made clear that emissions caused by human activity have led to a substantial increase in the concentration of greenhouse gases in the atmosphere. Based on calculations using computer models had shown that if the present rate of greenhouse gases in the atmosphere that for 30 years the average temperature of the globe will rise by about $1 \%$. In the face of the global threat of climate change, 1992 [1].

UN Conference on the environment on Wednesday in Rio de Janeiro UN member countries had signed the framework Convention on climate change.

Global climate change, as noted above, spend also agriculture. It is primarily the degradation of vegetation and soil cover. Together 
with human activities, namely the destruction of the forest with a high himizaciej of agriculture, unsustainable use irregular grazing lands, degradation leads to opustyvaniju territory. As a result, numerous exposed area of water, wind erosion, and desertification vnosledstvii. These processes are taking over our region [1-4].

\section{The object and method research}

In this situation, Professor B.g. Aliyev developed mathematical modeling of the process of desertification on the Absheron p-in on three points: Alat, and Mashtagi,Sumgait. The mathematical model of the development of desertification at proves Absheron [2]. Dryland degradation Processes now have acquired global dimensions and approaches for their solution proposed complex. This approach is embodied in an International Convention to combat desertification (UNCCD), adopted by the international community in 1994, 2011. The Convention to combat desertification defines this term as "land degradation in arid, semi-arid and dry sub-humid areas resulting from various factors, including climate change and human activity $[1]$.

Professor B.g. Aliyev noted that the aim of developing the creation of mathematical modeling is the accurate assessment of the impact of natural and anthropogenic factors on the process of desertification.

W desert combines multiple plots Ri. Both low density $\rho$ vegetation.

The rate of change of the desert area has the following equation;

$\frac{d s}{d t}=N+A(1)$

Here N-natural phenomena: a man-made;

W -desert: $S_{u}$-area of desert is characterized by the following formula:

$$
W-\sum \frac{R i}{\rho}<\rho \min (2)
$$

In here characteristics of the density of vegetation cover: $\mathrm{R}$ -region.

Thus Prof BH Aliyev mathematical modeling developed process of desertification: soil moisture model: model: karbonatizaci model salinization soil; soil temperature model; air temperature model; model soil erosion; models of deflation soil [1]. In the development of the deflation of the soil. When developing models of deflationwind erosion that is characteristic of the Gobustan district and situated on its territory, rangelands, designed the index of dryness.

$$
K_{c}=\frac{E}{p} \text { (3) }
$$

The number of the moved soil w. Lenilu will

$$
Q=\frac{c-v}{q}
$$

Here (c) is a constant of the soil: r-air density, $\mathrm{g} / \mathrm{cm}^{2} ; \mathrm{q}$ acceleration of free fall, $\mathrm{cm} / \mathrm{s}^{2} ; \mathrm{V}$-wind speed, see/see equation of blowing soil;

$$
\frac{d Q}{d t}=b c \frac{p}{g} y^{3} k_{c}
$$

$$
\frac{d Q}{d t}=B_{1} \frac{V}{(P-E)^{2}}
$$

\section{Analysis of studies}

To this end, we conducted research on winter pastures of Gobustan on 2013-2015 for soil characteristics skilled plot razrezdy were laid on the territory of Gobustan in $300 \mathrm{~km}$ west from of the maraza settlement on slabosmytyh and srednesmytyh (taupe Chestnut) soils.

The research found that the slabosmytye and srednesmytye grey-brown (Chestnut) soils vary in density of the solid phase, adding density, porosity, i.e. washed analogs, these figures are higher than in slabosmytyh that proves development of erosion. Mechanical composition of soil investigated smytostju weak medium loamy. In the upper horizon of physical clay content is $36.00 \%$, with the depth of the trend to increase. However, it should be noted that in srednesmytyh soil mechanical composition somewhat easier compared to non-eroded.

To this end, the experiments were performed at the winter pastures of Gobustan. Experiments were laid at the srednejerodirovannyh grey-brown (Chestnut) soils in repeated 3 hkratnoj, including 9 options. The area of each plot was $50 \mathrm{~m}^{2}$ (5x10m) with appropriate machinery: cleaning up the plot of weeds, stones etc field trials were established as follows:

1. Control b/fertilizer is natural grass

2. Lucerne

3. Onobrychis Transcaucasian

4. Perennial ryegrass

5. Fescue

6. Lucerne+ryegrass+ovjasnica

7. Onobrychis+ryegrass+ovjasnica

8. Lucerne+ryegrass+ovjasnica $+\mathrm{N}_{30} \mathrm{P}_{30} \mathrm{~K}_{30} \mathrm{~kg} / \mathrm{ha}$

9. Onobrychis+ryegrass+ovjasnica $+\mathrm{N}_{30} \mathrm{P}_{30} \mathrm{~K}_{30} \mathrm{~kg} / \mathrm{ha}$

When protecting the soil from erosion of the role of vegetation. Flora, as the wealth of the planet at the same time, an indispensable source of soil fertility. Both aboveground and underground mass of vegetation increases soil organic matter, which subsequently through the cycle of biochemical reactions increases gumifikaciju and nutrient status of the soil. 
From this point of view in enhancing soil fertility perennial herbs play a vital role, so the researchers while protecting soil from erosion, stress the advantage of perennial grasses like azotonakopitelej soil. On the basis of the foregoing was carried out seeding of perennial grasses, as well as their mixed planting with grasses and with the application of mineral fertilizers.

In field studies conducted by accounting for the harvest of forage grasses, average per 2013-2015, whose data are presented in the table below.

Here in control without fertilizers-natural herbage yield averaged 3.8 tons per hectare, with year of alfalfa planting $13.4 \mathrm{~kg} /$ ha with high yield 9.6kg/ha, sainfoin Transcaucasian $12.6 \mathrm{t} /$ ha with high $8.8 \mathrm{~kg} / \mathrm{ha}$, grasses-ryegrass grazing, Fescue-7.4kg/ha: $6.9 \mathrm{~kg} /$ ha. When making mineral fertilizers NPK rate of $30 \mathrm{~kg}$ per hectare of mixed seeding yield was $21.7 \mathrm{~kg} / \mathrm{ha}$ and $20.2 \mathrm{~kg} / \mathrm{ha}$ (Table 1$).$ One of the main agricultural soil fertility improvement tools is the use of mineral fertilizers.

The purpose of fertilizers is adding a nutrient to the soil, which lacks a plant to prevent soil erosion revegetation, is the main criterion. As can be seen from Table 1 productivity of legumes, cereals herbs and their mixed crops differ from natural grass [24]. Statistical processing of the results of research conducted on methods of A.m. Meshcheryakova (Table 1).

Table 1: Productivity of forage grasses winter pastures of Gobustan.

\begin{tabular}{|c|c|c|c|c|}
\hline \multirow{2}{*}{ S. No } & \multirow{2}{*}{ Options for Excellence } & \multicolumn{2}{|c|}{ Productivity } & \multirow{2}{*}{$\begin{array}{c}\text { The Increase of (average } \\
\text { 2013-2015g.) }\end{array}$} \\
\hline & & Green mass c/ha. & Medium c/ha. & \\
\hline 1 & $\begin{array}{c}\text { B control/fertilizers } \\
\text { natural grass }\end{array}$ & 11.5 & 3.8 & - \\
\hline 2 & Alfalfa & 40.1 & 13.4 & 9.6 \\
\hline 3 & Onobrychis Transcaucasian & 37.7 & 12.6 & 8.8 \\
\hline 4 & Perennial ryegrass & 22.1 & 7.4 & 3.6 \\
\hline 5 & Fescue & 20.6 & 6.9 & 3.1 \\
\hline 6 & Lucerne+ornamental grasses & 48.6 & 16.2 & 12.4 \\
\hline 7 & Onobrychis+ornamental grasses & 43.1 & 14.4 & 10.6 \\
\hline 8 & Lucerne+grain $+\mathrm{N}_{30} \mathrm{P}_{30} \mathrm{~K}_{30} \mathrm{~kg} / \mathrm{ha}$ & 65.2 & 21.7 & 14.1 \\
\hline 9 & Onobrychis+cereals $\mathrm{N}_{30} \mathrm{P}_{30} \mathrm{~K}_{30} \mathrm{~kg} / \mathrm{ha}$ & 60.6 & 20.2 & 16.4 \\
\hline
\end{tabular}

\section{Conclusion}

Experiments conducted on eroded ordinary gray-Brown (Chestnut) soils winter pastures of Gobustan. Under crops of herbs with the use of mineral fertilizers in mixed crops have had a positive impact on food soils.

As noted above, the arid climate of the region, coupled with environmental pollution Wednesday and anthropogenic impacts, including non-compliance with norms of grazing pasture degradation and led to the desertification of territory. However, the planting of perennial grasses in particular legume-cereal mixtures with granulated mineral fertilizers has had a positive effect on the nutrient status of soils studied.

Application of mineral fertilizers for crops, perennial grasses improves nitrifikacionnye processes associated with nitrogen nutrition. Improved soil nutritional status of positive responds to vital activity of perennial grasses, which in turn replenishes the soil organic material and restores fertility, which was seen as a method of combating erosion and pasture desertification.

\section{References}

1. Aliyev BH (2005) The problem of desertification in Azerbaijan and ways of its solution. p. 330 .

2. Aliev BH, Babaeva KM (2003) Factors related to the development of the desertification process. W-l Agrarian Science, Azerbaijan 1-3: 161-164.

3. Aliev BH, Babaeva KM (2007) Development models of desertification absheron n-VA. W-l agricultural science Azeri 1-3: 163-165.

4. Aliyev BH, Babaeva KM (2009) Development of soil erosion models p. Mashtagi to prevent desertification. W-l agricultural science 6: 71-75.
Creative Commons Attribution 4.0

International License

For possible submissions Click Here

\section{Submit Article}

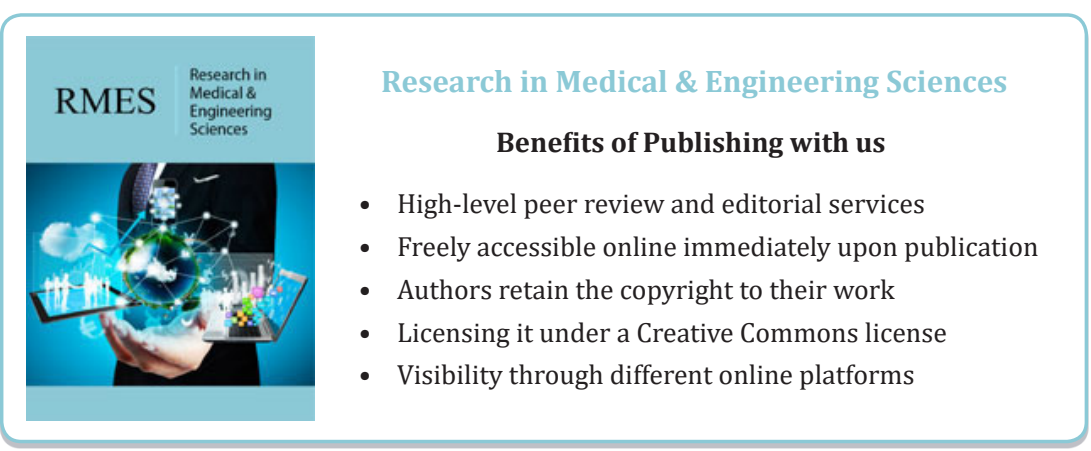

